\title{
ANALISA PENGARUH RANGSANGAN AROMATERAPI LAVENDER DAN KAYU CENDANA TERHADAP KUALITAS TIDUR BERBASISKAN GELOMBANG EEG
}

\author{
Alyani Durrah Fauzan ${ }^{1}$, Nushrotul Lailiyya ${ }^{2}$, Dwi Esti Kusumandari ${ }^{3}$, Fiky Yosef Suratman ${ }^{4}$ \\ ${ }^{1,4}$ Prodi S1 Teknik Elektro, Fakultas Teknik Elektro, Universitas Telkom, Bandung, Indonesia \\ ${ }^{2}$ Departemen Neurologi, Fakultas Kedokteran, Universitas Padjajaran, Bandung, Indonesia \\ ${ }^{3}$ UPT Balai Pengembangan Instrumentasi, Lembaga Ilmu Pengetahuan Indonesia \\ Bandung, Indonesia \\ $\left\{{ }^{1}\right.$ alyanifauzan, ${ }^{2}$ leilyantono, ${ }^{4}$ fysuratman $\} @$ gmail.com, ${ }^{3}$ esti_dek@yahoo.com
}

\begin{abstract}
Abstrak
Tidur merupakan aktivitas yang penting bagi tubuh. Aktivitas tidur membantu tubuh untuk menyembuhkan sel-sel yang rusak dan meningkatkan sistem kekebalan tubuh. Tetapi banyak dari kita yang tidak mendapatkan kualitas tidur yang baik untuk menerima manfaat tersebut. Demi meningkatkan kualitas tidur, sebagian besar masyarakat percaya bahwa penggunaan aromaterapi dapat membuat tubuh lebih rileks dan membantu penggunanya tidur lebih lelap. Penulis telah melakukan studi mengenai ada tidaknya pengaruh aromaterapi terhadap kualitas tidur dengan memanfaatkan sinyal biopotensial pada otak, yaitu electroencephalogram (Sinyal EEG). Sinyal EEG didapatkan dari proses akuisisi menggunakan Mitsar-EEG-202 dan software WinEEG. Selanjutnya, sinyal EEG akan dibaca secara visual berdasarkan bentuk, frekuensi, amplitudo, dan lokasi. Proses pembacaan sinyal akan menghasilkan nilai latensi tidur, durasi fase tidur (NREM dan REM), dan WASO. Data-data tersebut akan diuji secara manual (menghitung efisiensi tidur) per individu dan statistik (uji kesamaan dua rata-rata dan uji kesamaan dua varians). Hasil analisis secara statistik menunjukkan bahwa tidak adanya pengaruh yang signifikan antara subjek yang diberi stimulus aromaterapi terhadap subjek tanpa stimulus. Sedangkan pada analisis per individu, kualitas tidur dengan stimulus aromaterapi lebih baik dibandingkan tanpa stimulus pada beberapa subjek. Jika dihitung secara rata-rata, stimulus aromaterapi lavender dan kayu cendana dapat menaikkan efisiensi tidur, namun tidak signifikan.
\end{abstract}

Kata Kunci: Kualitas tidur, eeg, aromaterapi, uji statistik

Abstract

Sleep is an important activity for the body. Sleep activity helps the body to healing the damaged cells and boosting the immune system. But many of us are not getting a good sleep quality to receive the benefits of sleep. For increasing sleep quality, most people believe that the use of aromatherapy can make the body more relaxed and helps the users to sleep more soundly. This paper studies the aromatherapy effects on sleep quality seen from biopotential signals in the brain, the electroencephalogram (EEG Signal). EEG signals was obtained from the acquisition process using Mitsar-EEG-202 and WinEEG Software. Then, the EEG signal will be visually read according to shape, frequency, amplitude, and location. The process of reading the signal will produce the value of sleep latency, sleep phase duration (NREM and REM), and WASO. The data will be tested manually (calculating sleep efficiency) per individual and statistic (mean test and variance test). The results of statistical analysis showed that there was no significant influence between subjects who were given aromatherapy stimulus to the subject without stimulus. But in individual analysis, sleep quality with aromatherapy stimulus is better than without stimulus for some subjects. If calculated on average, lavender aromatherapy and sandalwood stimulus can increase sleep efficiency, but not significant.

Key Words: Sleep quality, eeg, aromatherapy, statistical test 


\section{Pendahuluan}

Tidur adalah aktifitas alamiah pada kehidupan manusia. Berdasarkan penelitian yang dilakukan oleh National Sleep Foundation, orang dewasa membutuhkan waktu tidur selama 89 jam setiap malam agar tubuh selalu dalam kondisi fit [1]. Tidur akan memberikan dampak positif jika memiliki kuantitas yang cukup dan kualitas yang baik. Baik atau buruknya kualitas tidur dapat berpengaruh pada mood dan kesehatan tubuh dalam jangka panjang. Kualitas tidur yang buruk biasanya disebabkan oleh beberapa faktor, contohnya insomnia, sleep apnea, mendengkur, kelainan ritme sikardian, sistem kerja shift, parasomnia, dll.

Otak manusia tetap aktif ketika tidur. Terutama saat bermimpi, otak akan bekerja layaknya sedang melakukan aktivitas di siang hari. Dari fakta inilah, kita bisa mengetahui kondisi tubuh dan kualitas tidur seseorang melalui sinyal otaknya. Sinyal otak yang biasa disebut electroencephalogram (EEG) merupakan sinyal gelombang yang memiliki amplitudo tegangan yang rendah, yaitu pada orde microvolt dalam rentang $100 \mathrm{uV}-1 \mathrm{mV}$.

Untuk mendukung penelitian ini, eksperimen dilakukan menggunakan stimulus berupa aromaterapi. Aromaterapi merupakan salah satu bentuk terapi relaksasi yang menggunakan sari tumbuhan untuk meningkatkan kesehatan tubuh, pikiran dan jiwa [2]. Setiap jenis aromaterapi memiliki manfaat yang berbeda-beda tehadap tubuh, salah satunya adalah membuat tubuh rileks dan mudah untuk tertidur lelap. Adapun aromaterapi yang digunakan pada penelitian ini adalah bunga lavender dan kayu cendana.

Penelitian mengenai kualitas tidur telah dilakukan di Panti Werdha Griya Asih Lawang dan Usia Tresno Mukti Turen Malang [2]. Penelitian tersebut diujikan pada 18 subjek yang berjenis kelamin wanita dengan rentang usia 60-69 tahun. Kesimpulan yang didapat dari penelitian tersebut adalah aromaterapi lavender dapat memberikan perbaikan kualitas tidur dan signifikan pada lansia yang mengalami gangguan kualitas tidur buruk.

Penelitian lainnya oleh Sandra Sgoutas-Emch [3], aromaterapi lavender dibuktikan efektif dalam mengurangi kecemasan dan stress di beberapa penelitian medis. Namun, pada subjek yang memiliki stres akut aromaterapi lavender tidak bekerja sama sekali. Kemudian pada penelitian yang dilakukan oleh Ryoko Masago dkk [4], disebutkan bahwa tiap aromaterapi memiliki efek menenangkan yang berbeda-beda. Kesimpulan pada penelitian tersebut menunjukkan bahwa aromaterapi kayu cendana (sandalwood) tidak menimbulkan perasaan nyaman di otak.

Pada penelitian yang lainnya [5], M. Fernandez dkk, menginvestigasi pengaruh aromaterapi lavender dan rosemary pada aktivitas otak sekelompok ibu yang menderita depresi dan tidak depresi. Penderita depresi cenderung akan mengalami gangguan tidur, sehingga memiliki kualitas tidur yang buruk. Hasil dari investigasi menunjukkan lavender dapat menurunkan aktivitas alpha pada daerah occipital dan parietal, serta meningkatkan aktivitas beta pada daerah frontal dan occipital, untuk kelompok ibu yang tidak depresi. Di sisi lain, lavender dapat meningkatkan aktivitas theta pada seluruh daerah otak untuk kelompok ibu yang depresi. Hal ini menyimpulkan bahwa aromaterapi lavender memberi manfaat yang baik bagi wanita dewasa dengan gangguan tidur.

Berbeda dengan penelitian yang telah diuraikan sebelumnya, penelitian pada paper ini diujikan pada 9 subjek berjenis kelamin laki-laki dengan rentang usia 20-23 tahun. Subjek penelitian diketahui tidak memiliki gangguan tidur. Seiring dengan pertambahan usia, jumlah total tidur orang dewasa tidak banyak berubah, akan tetapi kualitas tidur mengalami perubahan pada kebanyakan lansia. Keluhan tidur umumnya terjadi pada lansia, keluhan ini akan lebih banyak terjadi pada wanita daripada laki-laki dengan rasio 3:2 [6].

Pada penelitian ini, sinyal EEG diamati secara visual (manual), yakni dengan mengidentifikasi hasil akuisisi sinyal dari detik ke detik selanjutnya. Metode pembacaan manual merupakan metode yang cukup akurat untuk mengidentifikasi sinyal karena sinyal EEG tidak memiliki pola yang baku untuk setiap individu. Pembacaan sinyal secara otomatis atau pemrosesan sinyal digital dapat dilakukan tetapi memerlukan penelitian yang panjang dan dapat menjadi topik penelitian selanjutnya. Output dari penelitian ini adalah analisa pengaruh aromaterapi lavender dan kayu cendana terhadap kualitas tidur berdasarkan hasil akuisisi sinyal EEG saat tidur.

\section{Sinyal EEG dan Kualitas Tidur}

\subsection{Sinyal EEG}

Pada penelitian ini, yang menjadi masukan sistem adalah sinyal fisiologis pada otak manusia, yaitu sinyal EEG. Sinyal EEG adalah sinyal yang timbul akibat adanya aktivitas listrik yang terjadi di permukaan otak. Pada umumnya, sinyal EEG diklasifikasikan menurut frekuensi, amplitudo, bentuk, serta lokasi pada kulit kepala. Tabel 1 dan Tabel 2 menunjukkan beberapa jenis sinyal EEG berdasarkan frekuensi dan morfologi (bentuk).

\subsection{Tahapan Tidur}

Tidur terbagi menjadi 2 fase, yaitu Non Rapid Eye Movement (NREM) dan Rapid Eye Movement (REM). Fase NREM terbagi lagi dalam 4 tahap [9]. 
Tabel 1. Jenis Sinyal EEG Berdasarkan Frekuensi [7].

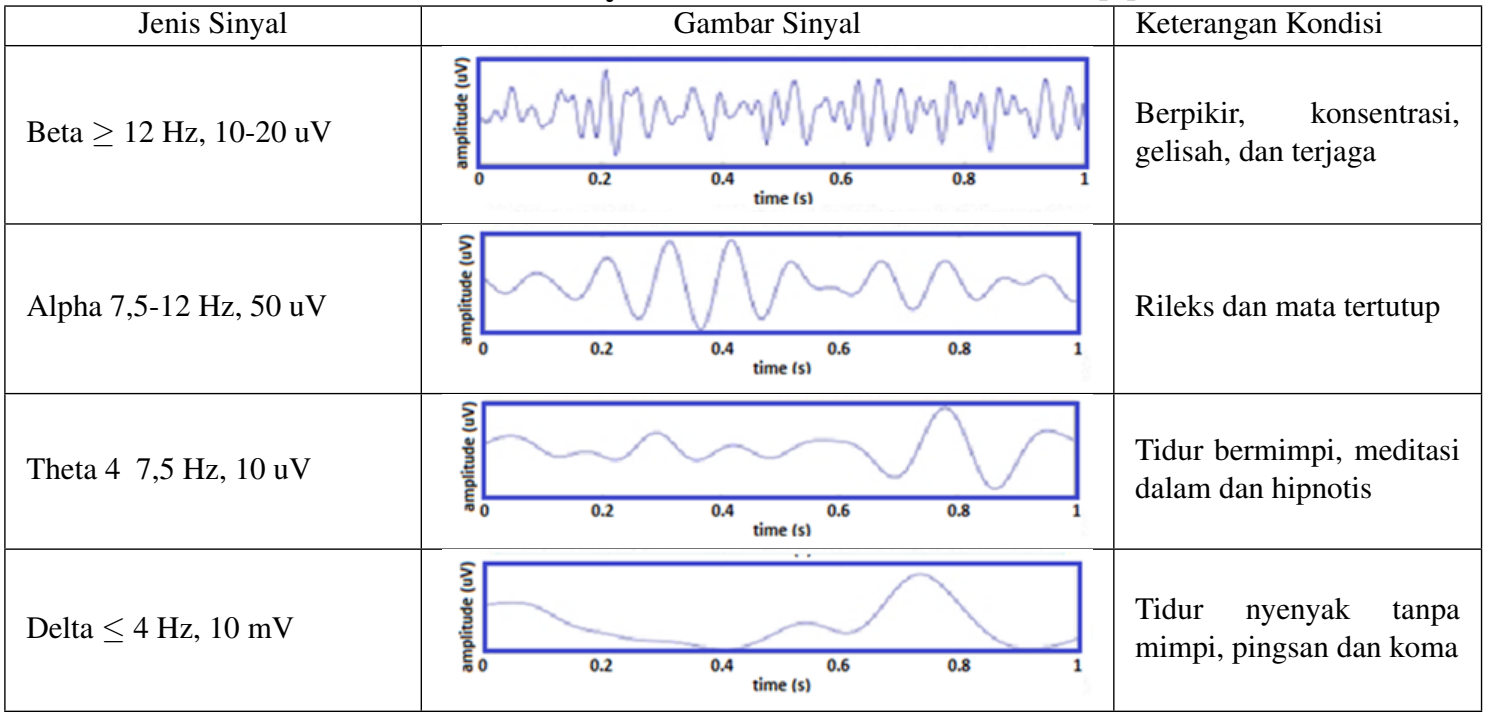

Tabel 2. Jenis Sinyal EEG Berdasarkan Morfologi [8]

\begin{tabular}{|c|c|c|}
\hline Jenis Sinyal & Keterangan & Gambar Sinyal \\
\hline K- Kompleks & $\begin{array}{l}\text { Memiliki amplitudo sangat besar dan tajam. } \\
\text { Muncul pada daerah bifrontal. }\end{array}$ & \multirow{2}{*}{ 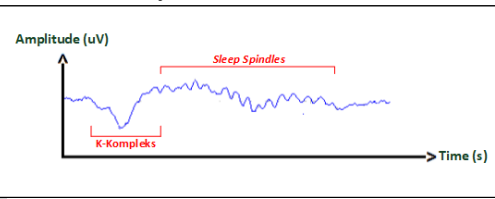 } \\
\hline Sleep Spindles & $\begin{array}{l}\text { Memiliki frekuensi antara alpha dan beta, } \\
\text { amplitudo cukup besar diawal yang kemudian } \\
\text { menurun perlahan. }\end{array}$ & \\
\hline Verteks & $\begin{array}{l}\text { Berbentuk sangat tajam pada montage } \mathrm{Fz}-\mathrm{Cz}-\mathrm{Pz} \text {. } \\
\text { Bentuk paling tajam ada pada Cz. }\end{array}$ & Amplitud \\
\hline Lambda & $\begin{array}{l}\text { Muncul pada daerah occipital. Dihasilkan saat } \\
\text { terjaga dan menatap permukaan kosong. }\end{array}$ & \multirow{2}{*}{ amplitude (UV) } \\
\hline POSTS & $\begin{array}{l}\text { Morfologi dan muncul di daerah yang sama seperti } \\
\text { Lambda. Namun dihasilkan saat tidur tahap } 1 \text { dan } \\
2 \text {. }\end{array}$ & \\
\hline
\end{tabular}

Setiap tahapan tidur memiliki karakteristik yang berbeda. Perbedaan karakteristik tersebut dapat dilihat pada Gambar 1 dan Tabel 3.

\subsection{Kualitas Tidur}

Salah satu fokus pada penelitian ini adalah menentukan kualitas tidur yang dimiliki seseorang. Kemudian membandingkan kualitas tidur antara pemberian stimulus dan tanpa stimulus pada eksperimen tidur. Kualitas tidur mencakup aspek kuantitatif dari tidur, seperti durasi tidur, latensi tidur serta aspek subjektif, seperti tingkat kelelapan tidur [11]. Adanya kualitas tidur yang buruk disebabkan seseorang mengalami gangguan kebutuhan tidur, seperti insomnia, hipersomnia, enuresis, narkolepsi dan sleep apnea [10]. Kualitas tidur dipengaruhi oleh banyak faktor, diantaranya adalah faktor psikologis dan stres, gaya hidup dan diet, kerja lembur, status kesehatan, serta obat-obatan [10].

Jika dikaitkan dengan tahapan tidur, kualitas tidur yang baik memiliki fase REM sekitar 20\% - 25\% dalam satu siklus. Selain itu, semakin panjang fase NREM 3 dan NREM 4 yang dilalui, maka akan semakin baik pula kualitas tidur. Berbeda halnya dengan nilai latensi tidur dan Wake After Sleep Onset (WASO), semakin besar durasi latensi tidur dan WASO maka kualitas tidur yang dihasilkan justru akan semakin buruk.

Menurut National Sleep Foundation [12], terdapat beberapa indikator kunci kualitas tidur yang baik. Indikator tersebut adalah memiliki durasi tidur setidaknya $85 \%$ dari total waktu tidur keseluruhan, durasi latensi tidur kurang dari 30 menit, tidak terbangun lebih dari sekali per malam, dan memiliki 


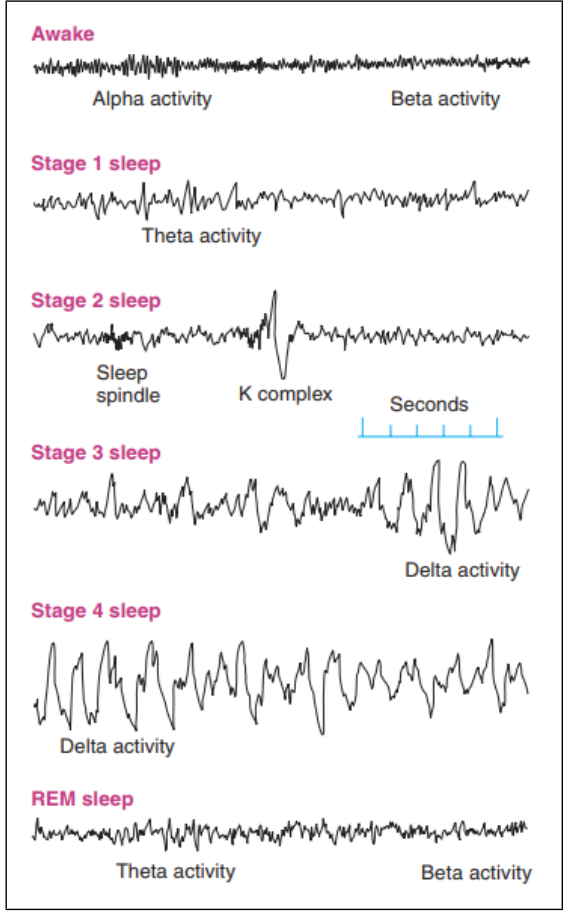

\section{Gambar 1. Perbedaan Bentuk Sinyal Tiap Fase Tidur [9].}

durasi bangun kurang dari 20 menit setelah awalnya tertidur.

\subsection{Aromaterapi}

Aromaterapi merupakan salah satu terapi komplementer yang dipercaya dapat meningkatkan kualitas tidur. Aromaterapi adalah penggunaan medis dari minyak esensial murni yang diekstrak dari tumbuhan [3]. Aromaterapi jenis tertentu memiliki efek menenangkan atau rileks untuk beberapa gangguan misalnya mengurangi kecemasan, ketegangan dan insomnia. Beberapa jenis aromaterapi yang bisa digunakan untuk terapi, antara lain Cajeput, Chamomile, Lemon, Basil, Orange Blossom, Lavender, dan lain-lain [13]. Setiap jenis aromaterapi memiliki khasiat yang berbeda. Contohnya Lavender (Lavendula Angustifolia) memiliki kandungan kimia linalyl atau linalool ester yang berkhasiat menenangkan dan cocok digunakan saat tidur [13].

\section{Metode dan Perancangan Sistem}

\subsection{Akuisisi Data}

Pengambilan data dilakukan pada 9 subjek yang berjenis kelamin laki-laki dengan rentang usia 20-23 tahun. Eksperimen dilakukan pada ruangan yang sama dan dikondisikan agar subjek dapat tertidur dengan nyaman. Pada eksperimen ini diberikan 2 buah stimulus, sehingga diperoleh data sampel dengan 3
Tabel 3. Perbedaan Karakteristik Fase Tidur

\begin{tabular}{|c|c|}
\hline Fase & Ciri-ciri \\
\hline Awake & $\begin{array}{l}\text { Adanya aktifitas alpha di daerah } \\
\text { occipital dan beta di frontal }\end{array}$ \\
\hline NREM 1 & $\begin{array}{l}\text { - Penurunan aktivitas alpha (alpha } \\
\text { on-off) } \\
\text { - Adanya gerakan mata } \\
\text { yang melambat (lateral eye } \\
\text { movement) di daerah frontal } \\
\text { - Munculnya Verteks di channel } \\
\text { Fz-Cz-Pz } \\
\text { - Munculnya POSTS di daerah } \\
\text { occipital }\end{array}$ \\
\hline NREM 2 & $\begin{array}{l}\text { - Adanya K-Kompleks dan sleep } \\
\text { spindles di daerah frontal } \\
\text { - Verteks dan POSTS lebih tajam } \\
\text { dibandingkan pada NREM } 1 \\
\text { - Terkadang terlihat aktifitas theta } \\
\text { di daerah temporal }\end{array}$ \\
\hline $\begin{array}{l}\text { NREM } \\
\text { dan } 4\end{array}$ & $\begin{array}{l}\text { - Aktifitas delta sebesar 20\%-50\% } \\
\text { pada NREM Tahap } 3 \\
\text { - Dominasi aktifitas delta lebih } \\
\text { dari } 50 \% \text { pada NREM Tahap } 4\end{array}$ \\
\hline REM & $\begin{array}{l}\text { REM dan sinyal saat terjaga memiliki } \\
\text { bentuk yang sama, hanya saja REM } \\
\text { memiliki sedikit aktivitas alpha. [10] }\end{array}$ \\
\hline
\end{tabular}

kondisi, yaitu kondisi tanpa stimulus, dengan stimulus aromaterapi lavender dan kayu cendana. Setiap eksperimen dilakukan pada siang hari dengan durasi perekaman 54-94 menit.

Alat deteksi EEG yang digunakan pada penelitian ini adalah electroencephalograph Mitsar-EEG-202 dengan pola penempatan elektroda sesuai prinsip 10-20 System [14]. 10-20 System merupakan standar penempatan elektroda yang banyak digunakan untuk merekam data EEG. Penempatan elektoda pada sistem ini meliputi seluruh daerah otak, yaitu frontal, parietal, temporal dan occipital. Terdapat 19 channel yang digunakan, diantaranya Fp1, Fp2, F7, F3, Fz, F4, F8, T3, C3, Cz, C4, T4, T5, P3, Pz, P4, T6, O1, O2, serta 2 channel referensi A1 dan A2 pada daun telinga. Pola penempatan elektroda dengan 10-20 System ditunjukkan pada Gambar 2(a). Sinyal EEG direkam dengan cara membandingkan tegangan antara dua elektroda pada kulit kepala. Tipe rekam EEG ini dinamakan tipe rekam EEG-Bipolar [15]. Tipe rekam EEG-Bipolar menghubungkan tiap channel elektroda dengan pola sebagai berikut : Fp1-F7, F7-T3, T3-T5, T5-O1, Fp2-F8, F8-T4, T4-T6, T6-O2, Fp1-F3, F3-C3, 
C3-P3, P3-O1, Fp2-F4, F4-C4, C4-P4, P4-O2, Fz-Cz, Cz-Pz. Gambar 2(b) menunjukkan peletakan tipe rekam EEG-Bipolar.

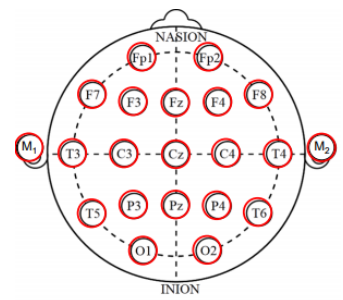

(a) 10-20 System [14]

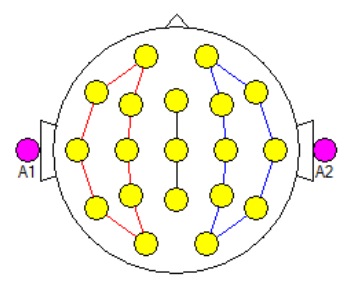

(b) EEG-Bipolar

\section{Gambar 2. Peletakan rekam EEG.}

Perangkat lunak yang digunakan pada proses perekaman sinyal EEG adalah WinEEG [16]. WinEEG merupakan perangkat lunak yang dirancang khusus untuk memproses sinyal yang diterima oleh electroencephalograph Mitsar-EEG-202. Terdapat beberapa hal yang harus diatur pada penggunaan software WinEEG ini, diantaranya: setting montage menjadi bipolar dengan prinsip 10-20 System, speed (skala horizontal) $30 \mathrm{~mm} / \mathrm{s}$, gain (skala vertikal) 100 $\mathrm{uV}$ atau $70 \mathrm{uV}$, low cut $0.3 \mathrm{~Hz}$, high cut $30 \mathrm{~Hz}$ dan frekuensi sampling $1000 \mathrm{~Hz}$.

\subsection{Uji Kesamaan Dua Rata-rata}

Data tidur yang sudah diolah akan diuji secara statistik menggunakan uji kesamaan dua rata-rata dan varians. Terdapat beberapa tahap pada pengujian kesamaan dua rata-rata, diantaranya [17]:

1. Menentukan Hipotesis Null (Ho) dan Hipotesis Alternatif (Ha), yang prinsipnya adalah menguji karakteristik populasi berdasar informasi yang diterima dari suatu sampel. Misal:

Ho $=$ Kedua rata-rata populasi adalah identik.

$\mathrm{Ha}=$ Kedua rata-rata populasi tidak identik.

2. Menentukan tingkat signifikansi $(\alpha)$, yaitu probabilitas kesalahan menolak hipotesis yang ternyata benar.

3. Menentukan statistik tabel dan statistik uji. Dalam uji rata-rata akan dicari $\mathrm{T}$ tabel dan $\mathrm{T}$ hitung. Keduanya dapat diperoleh dengan persamaan [18]:

$$
\begin{array}{r}
t_{\text {hitung }}=\frac{\bar{x}_{1}-\bar{x}_{2}}{\sqrt{\frac{s d_{1}^{2}}{n_{1}}+\frac{s d_{2}^{2}}{n_{2}}}}, \\
s d^{2}=\frac{n \sum x^{2}-\left(\sum x\right)^{2}}{n(n-1)},
\end{array}
$$

dimana, nilai $x$ merupakan data sampel, $\bar{x}$ menunjukkan nilai rata-rata sampel, $s d^{2}$ adalah nilai varians sampel, dan nilai $n$ menyatakan banyaknya data sampel. untuk nilai $T$ tabel dapat diperoleh dari tabel distribusi $T$ dengan persamaan [18]:

$$
T=t\left(1-\frac{1}{2} \alpha\right),\left(n_{1}-1\right)
$$

4. Mengambil kesimpulan Menerima Ho atau menolak Ha jika memenuhi kriteria berikut [18]:

$$
\begin{array}{r}
\text { Batas } 1<t_{\text {hitung }} \leq \text { Batas } 2 \\
-\frac{w_{1} t_{1}+w_{2} t_{2}}{w 1+w_{2}}<t_{\text {hitung }} \leq \frac{w_{1} t_{1}+w_{2} t_{2}}{w 1+w_{2}},
\end{array}
$$

dengan

$$
w=\frac{s d^{2}}{n} .
$$

Sedangkan jika tidak memenuhi kriteria tersebut, maka Ho ditolak atau Ha diterima.

\subsection{Uji Kesamaan Dua Varians}

Tahap yang harus ditempuh pada uji kesamaan dua varians adalah sama seperti uji kesamaan dua rata-rata. Cara mencari nilai $F_{\text {hitung }}$ adalah dengan membandingkan nilai varians yang lebih besar $\left(s d_{1}^{2}\right)$ dengan nilai varians yang lebih kecil $\left(s d_{2}^{2}\right), F_{\text {hitung }}$ dapat diperoleh dengan persamaan berikut [18]:

$$
F_{\text {hitung }}=\frac{s d_{1}^{2}}{s d_{2}^{2}},
$$

Sedangkan nilai $F_{\text {tabel }}$ diperoleh dari tabel distribusi $F$ dengan persamaan [18]:

$$
F_{\text {tabel }}=f\left(\frac{1}{2} \alpha\right),\left(n_{1}-1, n_{2}-1\right) .
$$

\section{Hasil dan Analisis Data}

Seperti yang ditunjukkan pada Gambar 3(a), hasil yang didapatkan dari proses akuisisi masih dalam bentuk raw data, sehingga perlu diolah dahulu sebelum dianalisis lebih lanjut. Pengolahan data yang dilakukan adalah mengklasifikasikan sinyal berdasarkan fase tidur dilihat dari ciri-ciri sinyal yang muncul. Sinyal akan diidentifikasi secara visual dari detik awal sampai detik terakhir. Total durasi setiap fase tidur yang dilalui subjek pada kondisi tanpa stimulus, dengan stimulus aromaterapi lavender dan kayu cendana ditunjukkan oleh Gambar 3(b) sampai dengan Gambar 5 Dari data pada Gambar 4, akan diperoleh nilai Total Sleep Time (TST), Total in Bed (TiB) dan efisiensi tidur. Perolehan nilainya dapat dilihat pada Tabel 4. Adapun rumus perhitungannya adalah sebagai berikut:

- Nilai TST, yaitu total tidur yang sebenarnya, tidak termasuk fase bangun diantara tahap tidur (WASO). Nilai ini didapatkan dari penjumlahan NREM Tahap 1, 2, 3, 4 (jika ada) dan REM (jika ada). 


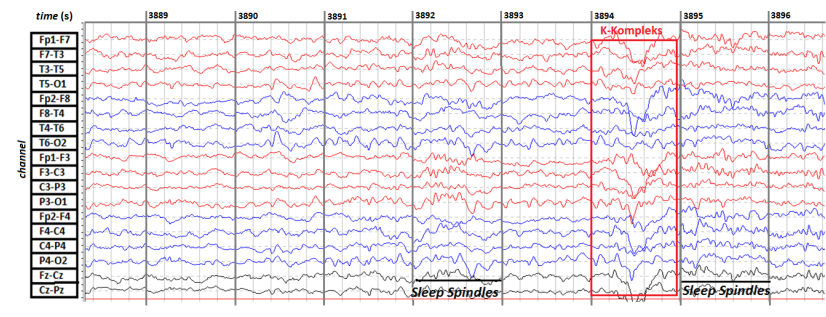

(a) Raw Data Hasil Akuisisi

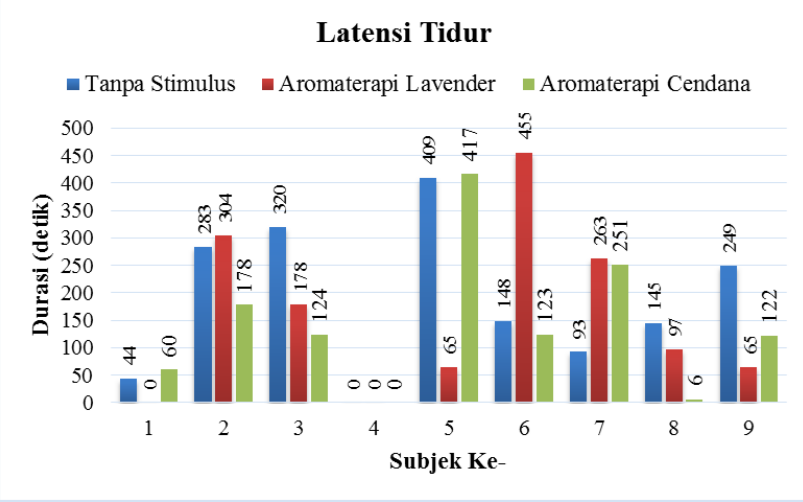

(b) Grafik Durasi Latensi Tidur

Gambar 3. Hasil penelitian.

- Nilai TiB, yaitu nilai total tidur sejak subjek pertama kali memejamkan mata sampai benar-benar bangun (total perekaman). Nilai ini dihitung dengan turut menjumlahkan nilai WASO dan latensi tidur.

- Nilai efisiensi tidur, yaitu persentase TST terhadap TiB.

\subsection{Analisis Data Secara Manual}

Tabel 5 menunjukkan hasil analisis data secara manual per individu pada stimulus aromaterapi lavender dan kayu cendana. Jika dihitung secara rata-rata, stimulus aromaterapi lavender dapat menaikkan efisiensi tidur hingga $8,32 \%$ dan aromaterapi kayu cendana mencapai 7,95\%. Hal ini menyimpulkan bahwa aromaterapi lavender dan kayu cendana tidak memiliki pengaruh yang signifikan untuk meningkatkan kualitas tidur, karena perbedaan efisiensi tidur yang diperoleh tidak terlalu besar. Namun jika dianalisis per individu, terdapat beberapa subjek yang kualitas tidurnya cenderung lebih baik dibandingkan kondisi tanpa stimulus. Hasil yang diperoleh pada tiap individu dipengaruhi oleh masing-masing kondisi tubuh dan psikologis individu tersebut.

\subsection{Analisis Statistik Aromaterapi Lavender}

Tabel 6 menunjukkan hasil analisis secara statistik menggunakan uji kesamaan dua rata-rata dan varians pada stimulus aromaterapi lavender. Kriteria

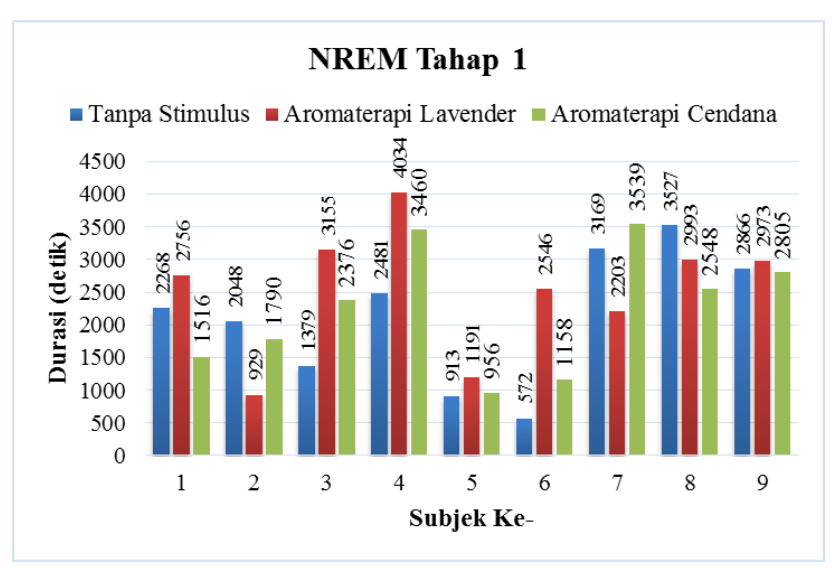

(a) NREM 1

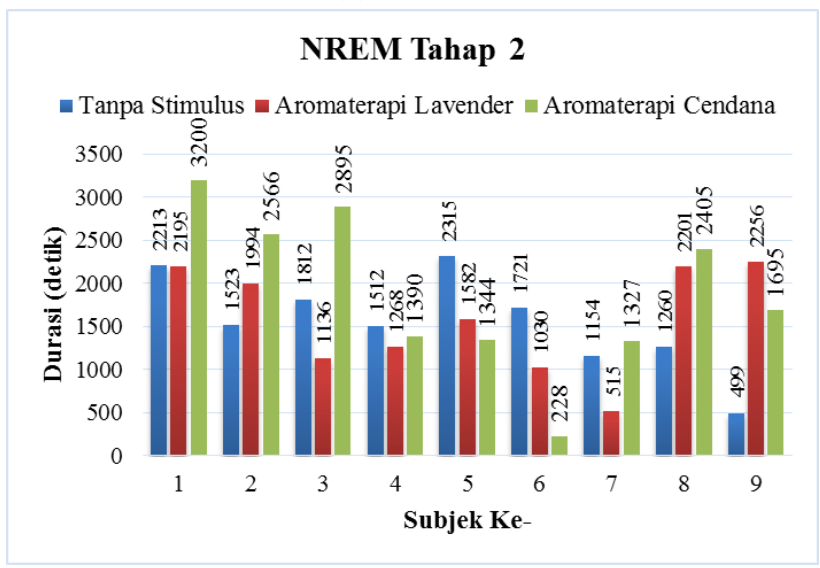

(b) NREM 2

\section{Gambar 4. Grafik Durasi Fase Tidur}

pengujian pada uji rata-rata adalah menerima Ho jika batas $1 \leq \mathrm{T}$ hitung $\leq$ batas 2 dan menolak Ho pada hal yang lainnya. Berdasarkan Tabel 6, dapat diketahui bahwa nilai $t$ hitung yang dihasilkan selalu berada pada daerah penerimaan Ho. Hal ini menyimpulkan bahwa tidak terdapat pengaruh antara stimulus aromaterapi lavender terhadap kondisi tanpa stimulus untuk nilai latensi tidur, NREM Tahap 1, 2, dan 3.

Kriteria pengujian pada uji varians adalah menerima Ho jika $\mathrm{F}$ hitung $\leq \mathrm{F}$ tabel dan menolak Ho jika $\mathrm{F}$ hitung $\geq \mathrm{F}$ tabel. Berdasarkan Tabel 6, F hitung yang dihasilkan selalu lebih kecil daripada $\mathrm{F}$ tabel, sehingga Ho diterima. Hasil pengujian menggunakan uji varians menunjukkan tidak adanya pengaruh aromaterapi lavender terhadap kondisi tanpa stimulus. Dengan demikian, penggunaan stimulus aromaterapi lavender tidak meningkatkan kualitas tidur secara signifikan, baik itu berdasarkan pengujian menggunakan uji rata-rata ataupun uji varians. 
Tabel 4. Nilai TST, TiB dan \% Efisiensi Tidur.

\begin{tabular}{|l|l|l|l|l|l|l|l|l|l|}
\hline \multirow{2}{*}{ Subjek } & \multicolumn{3}{|l|}{ Total Sleep Time (TST) } & \multicolumn{2}{l|}{ Total in Bed (TiB) } & \multicolumn{2}{l|}{ Efisiensi Tidur } \\
\cline { 2 - 9 } & $\begin{array}{l}\text { Tanpa } \\
\text { Stimulus }\end{array}$ & $\begin{array}{l}\text { Aroma } \\
\text { Lavender }\end{array}$ & $\begin{array}{l}\text { Aroma } \\
\text { Cendana }\end{array}$ & $\begin{array}{l}\text { Tanpa } \\
\text { Stimulus }\end{array}$ & $\begin{array}{l}\text { Aroma } \\
\text { Lavender }\end{array}$ & $\begin{array}{l}\text { Aroma } \\
\text { Cendana }\end{array}$ & $\begin{array}{l}\text { Tanpa } \\
\text { Stimulus }\end{array}$ & $\begin{array}{l}\text { Aroma } \\
\text { Lavender }\end{array}$ & $\begin{array}{l}\text { Aroma } \\
\text { Cendana }\end{array}$ \\
\hline 1 & 5171 & 5421 & 5129 & 5488 & 5223,22 & 5455 & 94,22 & 99,91 & 94,02 \\
\hline 2 & 3571 & 4031 & 5064 & 4965 & 4994 & 5499 & 71,92 & 80,72 & 92,09 \\
\hline 3 & 3216 & 4291 & 5379 & 5419 & 5518 & 5621 & 59,35 & 77,76 & 95,69 \\
\hline 4 & 4230 & 5341 & 4935 & 4612 & 5403 & 5402 & 91,72 & 98,85 & 91,36 \\
\hline 5 & 3917 & 3321 & 2364 & 5429 & 3655 & 3288 & 72,15 & 90,86 & 71,90 \\
\hline 6 & 2805 & 3596 & 1386 & 4268 & 5400 & 4632 & 65,72 & 66,59 & 29,92 \\
\hline 7 & 4381 & 2733 & 4866 & 5448 & 5433 & 5482 & 80,41 & 50,30 & 88,76 \\
\hline 8 & 4798 & 5453 & 5576 & 5526 & 5610 & 5612 & 86,83 & 97,20 & 99,36 \\
\hline 9 & 3365 & 5322 & 5082 & 5476 & 5521 & 5512 & 61,45 & 96,40 & 92,20 \\
\hline Mean & 3939,33 & 4389,89 & 4420,11 & 5181,22 & 5195,25 & 5167,00 & 75,97 & 84,29 & 83,92 \\
\hline
\end{tabular}

Tabel 5. Analisis Manual per Individu.

\begin{tabular}{|c|c|c|c|c|}
\hline \multirow[b]{2}{*}{ Subjek } & \multicolumn{2}{|l|}{ Aromaterapi Lavender } & \multicolumn{2}{|l|}{ Aromaterapi Kayu Cendana } \\
\hline & Uraian Singkat & $\begin{array}{l}\text { Kecenderungan } \\
\text { Kualitas Tidur }\end{array}$ & Uraian Singkat & $\begin{array}{c}\text { Kecenderungan } \\
\text { Kualitas Tidur }\end{array}$ \\
\hline 1 & $\begin{array}{c}\text { Efisiensi tidur naik } 5,69 \% \text {, tidur didominasi oleh } \\
\text { NREM } 1\end{array}$ & $\begin{array}{c}\text { Tidak lebih baik } \\
\text { ataupun buruk }\end{array}$ & $\begin{array}{c}\text { Efisiensi tidur turun } 0,2 \% \text {, terjadi pergeseran fase } \\
\text { tidur ke NREM } 2 \text { dan } 3\end{array}$ & Lebih baik \\
\hline 2 & $\begin{array}{c}\text { Efisiensi tidur naik } 8,8 \% \text {, terjadi pergeseran fase } \\
\text { tidur ke NREM } 2 \text { dan } 3\end{array}$ & Lebih baik & $\begin{array}{c}\text { Efisiensi tidur naik } 20,17 \% \text {, terjadi pergeseran fase } \\
\text { tidur ke NREM } 2 \text { dan } 3\end{array}$ & Lebih baik \\
\hline 3 & Efisiensi tidur naik $18,41 \%$ & Lebih baik & Efisiensi tidur naik 36,34\% & Lebih Baik \\
\hline 4 & Efisiensi tidur naik 7,13\% & Lebih baik & $\begin{array}{l}\text { Efisiensi tidur turun } 0,36 \% \text {, WASO lebih besar, } \\
\text { terjadi pergeseran fase tidur ke NREM } 1\end{array}$ & $\begin{array}{l}\text { Tidak lebih baik } \\
\text { ataupun buruk }\end{array}$ \\
\hline 5 & $\begin{array}{c}\text { Efisiensi tidur naik } 18,71 \% \text {, latensi tidur dan } \\
\text { WASO lebih kecil, tidak berpengaruh pada } \\
\text { NREM } 1,2 \text { dan } 3\end{array}$ & $\begin{array}{l}\text { Tidak lebih baik } \\
\text { ataupun buruk }\end{array}$ & $\begin{array}{l}\text { Efisiensi tidur turun } 0,25 \% \text {,tidak berpengaruh pada } \\
\text { NREM } 1,2 \text { dan } 3\end{array}$ & Lebih buruk \\
\hline 6 & $\begin{array}{c}\text { Efisiensi tidur naik } 0,87 \% \text {, latensi tidur dan } \\
\text { WASO lebih kecil, tidur didominasi oleh NREM1 }\end{array}$ & Lebih buruk & Efisiensi tidur turun $35,8 \%$ & Lebih buruk \\
\hline 7 & Efisiensi tidur turun $30,1 \%$ & Lebih buruk & $\begin{array}{l}\text { Efisiensi tidur naik 8,35\%, tidak berpengaruh pada } \\
\text { NREM } 1 \text { dan } 2, \text { tidak memiliki NREM } 3\end{array}$ & $\begin{array}{c}\text { Tidak lebih baik } \\
\text { ataupun buruk }\end{array}$ \\
\hline 8 & $\begin{array}{c}\text { Efisiensi tidur naik } 10,37 \% \text {, terjadi pergeseran } \\
\text { fase tidur ke NREM } 2 \text { dan } 3\end{array}$ & Lebih baik & $\begin{array}{c}\text { Efisiensi tidur naik } 12,53 \% \text {, terjadi pergeseran fase } \\
\text { tidur ke NREM } 2 \text { dan } 3\end{array}$ & Lebih baik \\
\hline 9 & Efisiensi tidur naik 34,95\% & Lebih baik & Efisiensi tidur naik 30,75\% & Lebih baik \\
\hline
\end{tabular}

Tabel 6. Analisis Statistik pada Stimulus Aromaterapi Lavender.

\begin{tabular}{|c|c|c|c|c|c|c|c|c|c|c|}
\hline & \multicolumn{4}{|c|}{ 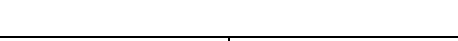 } & \multicolumn{3}{|c|}{ Uji Kesamaan Dua Rata-rata } & \multicolumn{3}{|c|}{ Uji Kesamaan Dua Varians } \\
\hline & \multicolumn{2}{|c|}{ Mean } & \multicolumn{2}{|c|}{ Varians } & \multirow[b]{2}{*}{$\begin{array}{c}T \\
\text { Hitung }\end{array}$} & \multirow[b]{2}{*}{$\begin{array}{l}\text { T Tabel (Batas } \\
1 \text { \& Batas 2) }\end{array}$} & \multirow[b]{2}{*}{ Ket } & \multirow[b]{2}{*}{ F Hitung } & \multirow[b]{2}{*}{ F Tabel } & \multirow[b]{2}{*}{ Ket } \\
\hline & $\begin{array}{c}\text { Tanpa } \\
\text { Stimulus }\end{array}$ & $\begin{array}{c}\text { Aroma } \\
\text { Lavender }\end{array}$ & $\begin{array}{c}\text { Tanpa } \\
\text { Stimulus }\end{array}$ & $\begin{array}{c}\text { Aroma } \\
\text { Lavender }\end{array}$ & & & & & & \\
\hline Latensi Tidur & 187,889 & 158,556 & 18445,61 & 23986,78 & 0,4272 & $-2,31$ dan 2,31 & Ho diterima & 1,300406 & 4,433275 & Ho diterima \\
\hline NREM 1 & 2135,889 & 2531,111 & 1024242 & 947203,9 & $-0,8444$ & $-2,31$ dan 2,31 & Ho diterima & 1,0813321 & 4,433275 & Ho diterima \\
\hline NREM 2 & 1556,556 & 1575,22 & 308747,8 & 390405,2 & $-0,0670$ & $-2,31$ dan 2,31 & Ho diterima & 1,264479 & 4,433275 & Ho diterima \\
\hline NREM 3 & 246,889 & 283,556 & 90582,11 & 137888,8 & $-0,2301$ & $-2,31$ dan 2,31 & Ho diterima & 1,522252 & 4,433275 & Ho diterima \\
\hline
\end{tabular}

Tabel 7. Analisis Statistik pada Stimulus Aromaterapi Kayu Cendana.

\begin{tabular}{|c|c|c|c|c|c|c|c|c|c|c|}
\hline & \multicolumn{4}{|c|}{ 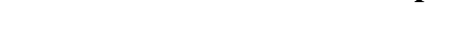 } & \multicolumn{3}{|c|}{ Uji Kesamaan Dua Rata-rata } & \multicolumn{3}{|c|}{ Uji Kesamaan Dua Varians } \\
\hline & \multicolumn{2}{|c|}{ Mean } & \multicolumn{2}{|c|}{ Varians } & \multirow[b]{2}{*}{$\begin{array}{c}\text { T } \\
\text { Hitung }\end{array}$} & \multirow[b]{2}{*}{$\begin{array}{c}\text { T Tabel (Batas } \\
1 \text { \& Batas 2) }\end{array}$} & \multirow[b]{2}{*}{ Ket } & \multirow[b]{2}{*}{$\begin{array}{c}\text { F } \\
\text { Hitung }\end{array}$} & \multirow[b]{2}{*}{ F Tabel } & \multirow[b]{2}{*}{ Ket } \\
\hline & $\begin{array}{c}\text { Tanpa } \\
\text { Stimulus }\end{array}$ & $\begin{array}{c}\text { Aroma } \\
\text { Cendana }\end{array}$ & $\begin{array}{c}\text { Tanpa } \\
\text { Stimulus }\end{array}$ & $\begin{array}{c}\text { Aroma } \\
\text { Cendana }\end{array}$ & & & & & & \\
\hline Latensi Tidur & 187,889 & 142,333 & 18445,61 & 16908,8 & 0,7268 & $n 2,31$ & Ho dite & 1,09089 & 4,433275 & Ho diterima \\
\hline NREM 1 & 2135,889 & 2238,67 & 1024242 & 894303 & $-0,2226$ & n 2,31 & Ho dite & 1,1453 & 4,433275 & Ho diterima \\
\hline NREM 2 & 1556,556 & 1894,44 & 308747,8 & 889188 & $-0,9261$ & $-2,31$ dan 2,31 & Ho diterima & 2,87998 & 4,433275 & Ho diterima \\
\hline NREM 3 & 246,889 & 287 & 90582,11 & 85043,8 & $\begin{array}{l}-0,2871 \\
\end{array}$ & $-2,31$ dan 2,31 & Ho diterima & 1,06512 & 4,433275 & Ho diterima \\
\hline
\end{tabular}

\subsection{Analisis Statistik pada Aromaterapi Kayu Cendana}

Tabel 7 menunjukkan hasil analisis secara statistik menggunakan uji kesamaan dua rata-rata dan varians pada stimulus aromaterapi kayu cendana. Hasil pengujian stimulus aromaterapi kayu cendana memperlihatkan hasil yang sama dengan aromaterapi lavender. Berdasarkan pada Tabel 7, nilai statistik

Analisa Pengaruh Rangsangan Aromaterapi Lavender dan Kayu Cendana Terhadap Kualitas Tidur Berbasiskan 


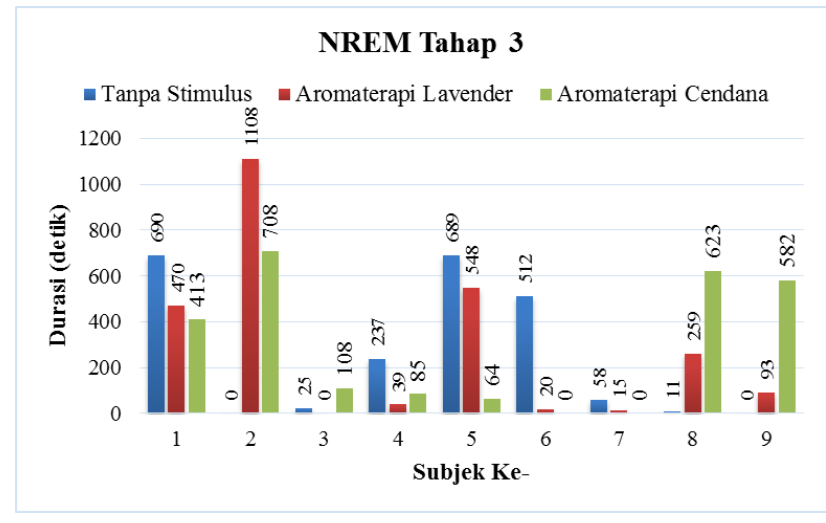

(a) NREM 3

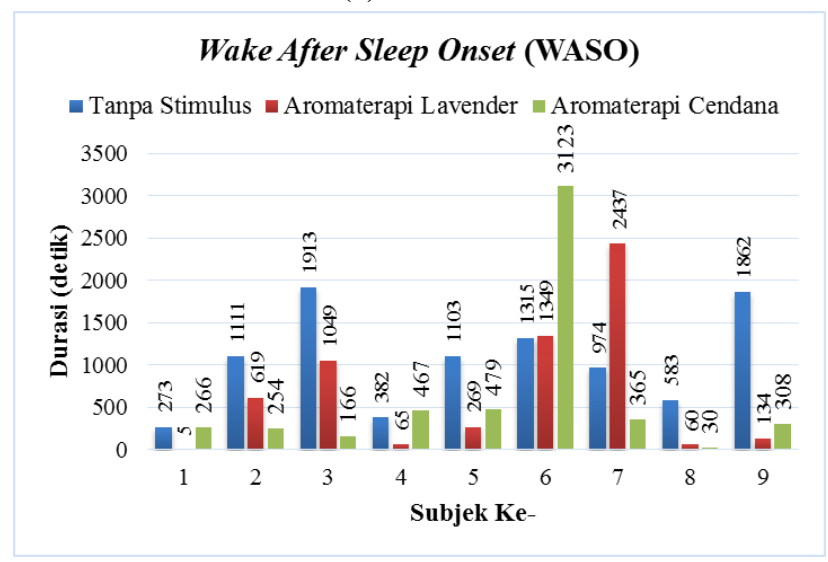

(b) Wake After Sleep Onset (WASO)

\section{Gambar 5. Grafik Durasi}

hitung ( $\mathrm{T}$ hitung dan $\mathrm{F}$ hitung) selalu berada pada daerah penerimaan Ho untuk nilai latensi tidur, NREM Tahap 1, 2, dan 3. Sehingga, kesimpulan yang dapat diambil adalah penggunaan stimulus aromaterapi kayu cendana tidak memiliki pengaruh pada kondisi tanpa stimulus secara statistik.

\section{Kesimpulan}

Eksperimen dilakukan pada 9 orang mahasiswa laki-lak idan berusia 20-23 tahun. Eksperimen dikerjakan pada siang hari dengan 3 perlakuan (tanpa stimulus, dengan stimulus lavender dan kayu cendana) selama 54-94 menit per eksperimen. Berdasarkan penelitian tersebut, dapat disimpulkan:

- Pada analisis secara manual per individu, terdapat 6 subjek yang kualitas tidurnya cenderung meningkat setelah pemberian stimulus aromaterapi lavender, 2 subjek kualitas tidurnya cenderung menurun dan 1 subjek menunjukkan hasil yang tidak jauh berbeda dengan kondisi tanpa stimulus. Sedangkan pada pemberian sti mulus aromaterapi kayu cendana, terdapat 5 subjek yang kualitas tidurnya cenderung meningkat setelah pemberian stimulus aromaterapi lavender, 2 subjek kualitas tidurnya cenderung menurun dan 2 subjek tidak terpengaruh apapun. Jika dilihat secara rata-rata, stimulus aromaterapi lavender dapat menaikkan efisiensi tidur hingga 8,32\% dan aromaterapi kayu cendana mencapai $7,95 \%$.

- Secara statistik penggunaan aromaterapi lavender dan kayu cendana tidak memiliki pengaruh terhadap kondisi tanpa stimulus. Hal ini berlaku pada seluruh nilai yang diujikan, yakni nilai latensi tidur, NREM 1, 2 dan 3.

- Selain aspek kuantitatif (latensi tidur, durasi tidur, efisiensi tidur), banyak aspek subjektif yang terlibat pada penelitian kualitas tidur. Aspek-aspek tersebut diantaranya usia, tingkat kelelapan tidur, tingkat stres, dll. Penelitian ini dilakukan pada subjek yang usianya relatif muda sehingga kualitas tidur dengan atau tanpa stimulus aromaterapi tidak akan jauh berbeda.

\section{Daftar Pustaka}

[1] Anonim, "How much sleep do we really need?" https://sleepfoundation.org/excessivesleepiness/ content/how-much-sleep-do-we-really-need-0, February 2018.

[2] A. D. Kurnia, V. Wardhani, and K. T. Rusca, "Aromaterapi bunga lavender memperbaiki kualitas tidur pada lansia," Jurnal Kedokteran Brawijaya, vol. 25, no. 2, pp. 83-86, 2013.

[3] S. Sgoutas-Emch, T. Fox, M. Preston, C. Brooks, and E. Serber, "Stress management: Aromatherapy as an alternative," Sci. Rev. Altern. Med, vol. 5, pp. 90-95, 2001.

[4] R. Masago, T. Matsuda, Y. Kikuchi, Y. Miyazaki, K. Iwanaga, H. Harada, and T. Katsuura, "Effects of inhalation of essential oils on eeg activity and sensory evaluation," Journal of Physiological Anthropology and Applied Human Science, vol. 19, no. 1, pp. 35-42, 2000.

[5] M. Fernandez, EEG during Lavender and Rosemary Exposure in Infants of Depressed and Non-depressed Mothers. Infant Behavior \& Development, 27, 91-100, USA, 2004.

[6] F. Solomon, "Report of a study: sleeping pills, insomnia and medical practice," Washington, DC.: Institute of Medicine, 1979.

[7] A. Azhari, "Studi perbandingan : Cognitive task berdasarkan hasil ekstraksi ciri gelombang otak," in Seminar Nasional Teknologi Informasi dan Multimedia STMIK AMIKOM, 2015. 
[8] R. Suchelekiy, "Normal eeg waveforms," https://emedicine.medscape.com/article/ 1139332-overview, February 2018.

[9] S. R. Benbadis, "Normal sleep eeg," https://emedicine.medscape.com/article/ 1140322-overview, February 2018.

[10] S. Mareti, Pengaruh Gabungan Sugesti dan Musik Instrumelia Terhadap Peningkatan Kualitas Tidur pada Lansia di Griya Lansia Santo Yosef Surabaya. Universitas Airlangga, 2015.

[11] I. A. Silvanasari, Faktor faktor yang Berhubungan dengan Kualitas Tidur yang Buruk pada Lansia di Desa Wonojati Kecamatan Jenggawah Kabupaten Jember. Universitas Jember, 2012.

[12] Anonim, "What is good quality sleep?" https://sleepfoundation.org/press-release/ what-good-quality-sleep, May 2018.

[13] C. Kurniasari, Pengaruh Aromaterapi Terhadap Penurunan Kejadian Insomnia pada Usia Lanjut di Dusun Kramen VI Sido Agung Godean Sleman Yogyakarta. Sekolah Tinggi Ilmu Kesehatan Aisyiyah, 2010.

[14] A. Moley, "10-20 system eeg placemen," http://www.ers-education.org/lrmedia/2016/pdf/ 298830.pdf, January 2018.

[15] R. S. Khandpur, Biomedical Instrumentation, Technology and Application 2nd Edition. Tata McGraw-Hill Education, 2014.

[16] M. C. Ltd, Software for Electroencephalogram Acquisition and Processing, WinEEG User Manual. Rusia : Mitsar Co.Ltd, 2006.

[17] A. Santosa, Purbayu B, Analisis Statistik dengan Microsoft Excel \& SPSS. Yogyakarta : ANDI OFFSET, 2005.

[18] Sudjana, Metoda Statistika. Tarsito, 2005.

Analisa Pengaruh Rangsangan Aromaterapi Lavender dan Kayu Cendana Terhadap Kualitas Tidur Berbasiskan 